Article

\title{
Preparation of Breathable Cellulose Based Polymeric Membranes with Enhanced Water Resistance for the Building Industry
}

\author{
Atif Hussain * and Pierre Blanchet (D
}

check for

updates

Citation: Hussain, A.; Blanchet, P. Preparation of Breathable Cellulose Based Polymeric Membranes with Enhanced Water Resistance for the Building Industry. Materials 2021, 14 , 4310. https://doi.org/10.3390/ ma14154310

Academic Editor: Carlos

Morón Fernández

Received: 8 July 2021

Accepted: 29 July 2021

Published: 1 August 2021

Publisher's Note: MDPI stays neutral with regard to jurisdictional claims in published maps and institutional affiliations.

Copyright: (c) 2021 by the authors. Licensee MDPI, Basel, Switzerland. This article is an open access article distributed under the terms and conditions of the Creative Commons Attribution (CC BY) license (https:/ / creativecommons.org/licenses/by/ $4.0 /)$.
Department of Wood and Forest Sciences, Université Laval, Quebec City, QC G1V 0A6, Canada; pierre.blanchet@sbf.ulaval.ca

* Correspondence: atif.hussain.1@ulaval.ca

\begin{abstract}
This study focuses on the development of advanced water-resistant bio-based membranes with enhanced vapour permeability for use within building envelopes. Building walls are vulnerable to moisture damage and mold growth due to water penetration, built-in moisture, and interstitial condensation. In this work, breathable composite membranes were prepared using micro-fibrillated cellulose fiber (CF) and polylactic acid (PLA). The chemical composition and physical structure of $\mathrm{CF}$ is responsible for its hydrophilic nature, which affects its compatibility with polymers and consequently its performance in the presence of excessive moisture conditions. To enhance the dispersibility of CF in the PLA polymer, the fibers were treated with an organic phosphoric acid ester-based surfactant. The hygroscopic properties of the PLA-CF composites were improved after surfactant treatment and the membranes were resistant to water yet permeable to vapor. Morphological examination of the surface showed better interfacial adhesion and enhanced dispersion of CF in the PLA matrix. Thermal analysis revealed that the surfactant treatment of CF enhanced the glass transition temperature and thermal stability of the composite samples. These bio-based membranes have immense potential as durable, eco-friendly, weather resistant barriers for the building industry as they can adapt to varying humidity conditions, thus allowing entrapped water vapor to pass through and escape the building, eventually prolonging the building life.
\end{abstract}

Keywords: cellulose fiber; vapor permeability; surface treatment; surfactant; bio-based materials

\section{Introduction}

The accumulation of water in the form of excessive moisture within building envelopes can lead to the premature deterioration of building materials [1]. Buildings can be affected by three main sources of moisture: external moisture from precipitation or groundwater; internal moisture from occupant presence and their activities; and built-in moisture in the materials accumulated during manufacturing. Moisture movement in building wall cavities is facilitated by air currents, heat transfer and diffusion through materials. The penetration and accumulation of excessive moisture in building envelopes can lead to interstitial condensation, which can cause structural damages, mould growth, as well as damage to indoor materials. The moisture flow in building envelopes can be controlled by using barriers in walls, floors, ceiling, and roofs, thereby preventing interstitial condensation [2].

Weather barriers are membranes used in the exterior side of the wall system and act like a shell for buildings [3]. A premium, high-performance weather barrier has four beneficial and essential functions: air resistance, water resistance, durability during construction, and the right level of vapor permeability. Although the process of vapour permeability is least understood and heavily ignored, it can greatly affect the wall performance [4]. Vapor permeability is also discussed in terms of breathability of the material as its ability to allow moisture or water vapour to pass through it $[5,6]$. A good weather barrier is expected to resist bulk water (in liquid form) but should not necessarily block water vapour (in gas 
form) [7]. In the past, installing barriers in envelopes was not necessary as the walls had very low insulation. However, in the current scenario when the wall interior gets wet, tighter enclosures combined with high levels of thermal insulation can significantly reduce the drying potential of the wall [8]. Vapor barriers have been used with the intention to protect walls from becoming wet, however their main disadvantage is that the barrier also prevents from drying if the interior of the walls get wet [9]. Therefore, there is a need to develop a barrier with a unique structure that can specifically allow vapour to pass through but resist water entering the building wall. The most common barriers currently used in industry are non-biodegradable fossil fuel-based, which also raises the need to develop new barriers with more sustainable properties.

Bio-based materials have recently become popular in the building and construction industry due to their insulation and hygroscopic properties $[10,11]$. Studies have reported that using these materials in construction increases the energy efficiency of the building and provide a comfortable and healthy indoor environment [12-14]. Some bio-based materials also have the ability to absorb and release moisture with respect to changing relative humidity levels, which can reduce the load on air conditioning and have a positive impact on wellbeing of residents $[15,16]$. The ability of bio-based materials to capture and lock $\mathrm{CO}_{2}$ from the atmosphere during their lifetime can be highly beneficial for the environment [17]. The Quebec building code highlights that greenhouse gas emissions from buildings account for a large share of the region's overall emissions and strives to achieve its emission reduction targets by 2030 [18]. To accomplish this goal, buildings should have a highly energy efficient design as well as lower embodied energy. Since majority of the electricity generated for use in Quebec buildings is derived from hydroelectricity, which is a renewable source, the embodied energy of buildings plays a major role in contributing towards carbon emissions during their life cycle [19]. Quebec has immense potential for developing new renewable materials from wood by-products that will result in the production extremely lower embodied energy materials.

Cellulose is the most abundant organic compound, and it can be obtained quite easily from wood pulp in the form of very thin and long fibers. Recent advancements in science have supported the development of industrial processes for the extraction of cellulose fiber from wood in large-scale volumes, having a $100 \%$ yield without the use of enzymes or chemicals [20]. The fibres have unique properties such as high specific surface area, good strength and rheological properties making them a highly versatile, biodegradable, and compostable additive for a composite as either a membrane or a coating. Recent studies have used cellulose fibres for the development of films addressing mechanical [21,22] and optical properties $[23,24]$. However, a few studies have reported excellent vapor barrier properties in packaging applications [25-27] and their use in the construction industry [28].

Cellulose is highly hydrophilic due to the presence of hydroxyls in its chemical structure. High moisture sensitivity in bio-based materials can lead to fungal growth and compromise the durability of the material [29]. Furthermore, the quality of the end product can be affected during the manufacturing stages if cellulosic materials encounter humid environments or unexpected water [30]. The high water absorption capacity of biobased materials also makes them incompatible with hydrophobic polymers causing poor interfacial adhesion in the composites [31,32]. Numerous studies have investigated the effect of alkali [33], acetylation [34], ionic liquids and salts [35-37], silane [38], sol-gel [39], and surfactant $[40,41]$ treatment of bio-based materials that improve their hydrophobicity and compatibility with polymers.

Cellulose fibers offer wide possibilities for new product development and the objective of this research is the utilization of commercially available cellulose fibers with a bio-based polymer for the development of a breathable vapor barrier for the construction industry. The work also involves the treatment of the cellulose fibers and an investigation of their compatibility with the polymer to determine the vapor permeability, morphology, as well as physical and thermal characteristics of the composite material. 


\section{Materials and Methods}

Cellulose fibers commercially referred as cellulose filaments were received from Kruger Biomaterials Inc. (Montreal, QC, Canada), a privately held company that transforms renewable resources into sustainable essentials. The cellulose fibers used in this study were obtained in the form of suspension $(2.5 \mathrm{wt} \%)$. The fibers were obtained by freeze-drying the suspension. PLA grade 4043D was used in this study and obtained from NatureWorks (Minnetonka, MN, USA). This particular grade of PLA is targeted for the preparation of membranes and films. Chloroform was used as the solvent for dissolving PLA and obtained from Sigma-Aldrich (Oakville, ON, Canada).

\subsection{Fiber Treatment}

For the treatment of cellulose fibers, an organic phosphoric acid ester-based surfactant was added to the CF suspension. The surfactant was obtained from EMCO-Inortech (Shwego-wett 6267), Montreal, QC, Canada. It is a biodegradable, VOC-free, anionic universal wetting, and dispersive additive. The concentration of surfactant used for treatment of the fibers was $20 \mathrm{wt} \%$ of dry fiber weight. The fiber suspension along with the surfactant was mixed using a high shear mixer at $2000 \mathrm{rpm}$ for $15 \mathrm{~min}$ and then freeze-dried.

\subsection{Film Preparation}

PLA membranes were prepared using solvent casting method. Briefly, $5 \mathrm{~g}$ of PLA was dissolved in $100 \mathrm{~mL}$ of chloroform under constant stirring at $600 \mathrm{rpm}$ for $2 \mathrm{~h}$ at room temperature and atmospheric pressure. The solution was poured into a Petri dish and left in a fume hood at room temperature for evaporating the solvent. For preparation of the $\mathrm{CF}$ composite membranes, varying concentrations of untreated and surfactant treated $\mathrm{CF}$ were the added to dissolved PLA and stirred vigorously for another $30 \mathrm{~min}$ using a high shear mixer at $1200 \mathrm{rpm}$. At the end of the mixing process, the PLA-CF solution was homogenous, and no bubbles were observed. The prepared PLA membranes with varying concentrations of untreated cellulose fibers (UCF) and treated cellulose fibers (TCF) used for this study are mentioned in Table 1. Micrographs showing UCF and TCF are presented in Figure 1. Photographs of all prepared films used in this experiment are shown in Figure 2. All membrane samples were vacuum dried at $40{ }^{\circ} \mathrm{C}$ for $96 \mathrm{~h}$ to release any remaining solvent and then sealed and stored in zipped airtight bags for characterization.

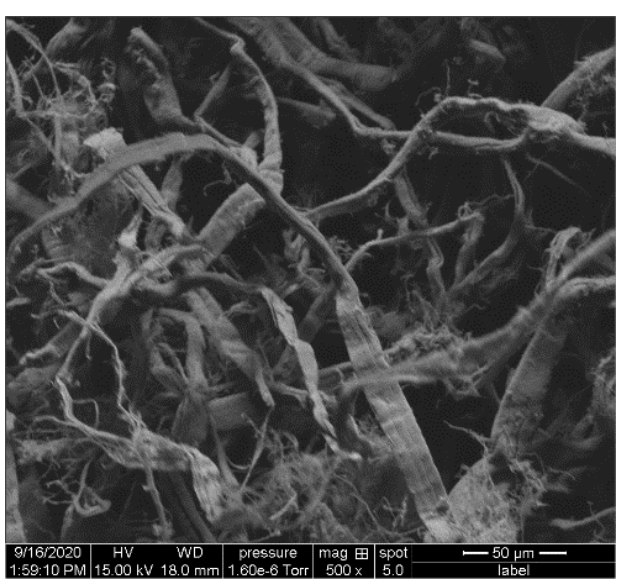

(a)

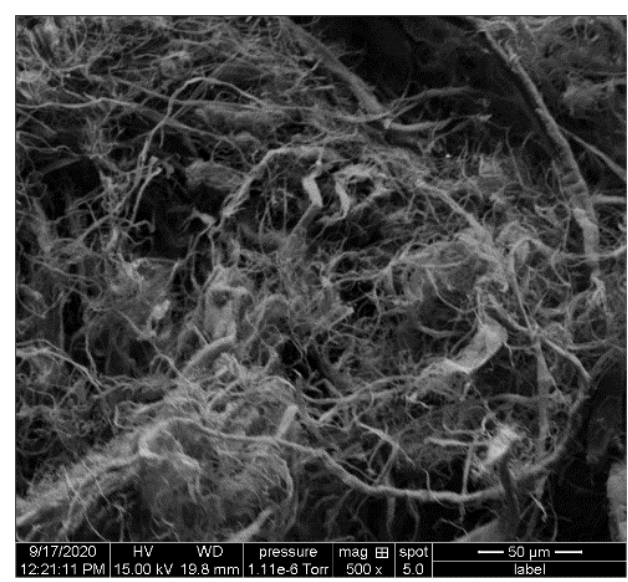

(b)

Figure 1. Micrographs of cellulose fibers (a) untreated, (b) after surfactant treatment. 
Table 1. Description of film samples prepared for this study.

\begin{tabular}{cccc}
\hline Sample & PLA Conc. $(\mathbf{w t} \%)$ & CF Conc. $\mathbf{( w t} \%)$ & Surfactant Treated \\
\hline PLA & 100 & 0 & - \\
UCF & 0 & 100 & - \\
TCF & 0 & 100 & Yes \\
PLA-UCF1 & 99 & 1 & - \\
PLA-UCF2 & 98 & 2 & - \\
PLA-UCF5 & 95 & 5 & - \\
PLA-UCF10 & 90 & 10 & - \\
PLA-UCF15 & 85 & 15 & - \\
PLA-UCF20 & 80 & 20 & - \\
PLA-TCF1 & 99 & 1 & Yes \\
PLA-TCF2 & 98 & 2 & Yes \\
PLA-TCF5 & 95 & 5 & Yes \\
PLA-TCF10 & 90 & 10 & Yes \\
PLA-TCF15 & 85 & 15 & Yes \\
PLA-TCF20 & 80 & 20 & Yes \\
\hline
\end{tabular}

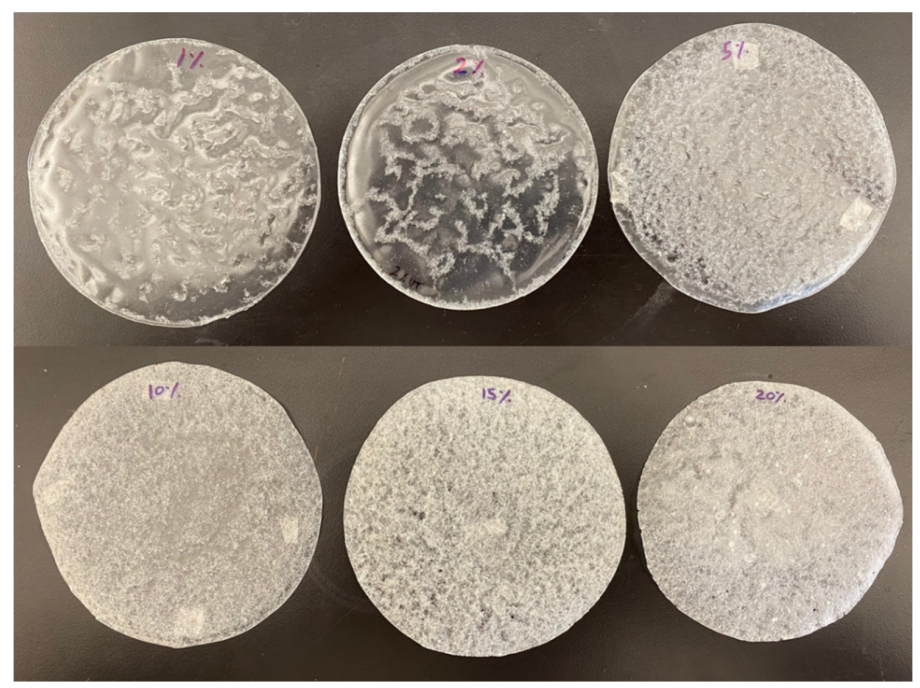

(a)

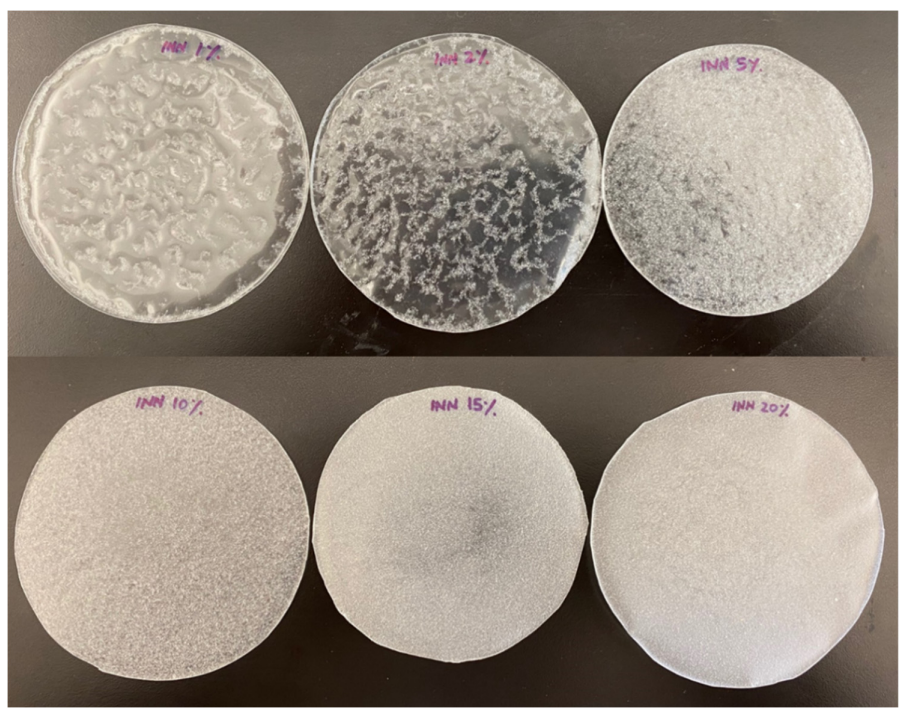

(b)

Figure 2. Photographs of (a) PLA-UCF films with 1-20\% UCF content; (b) PLA-TCF films with 1-20\% TCF content. 


\subsection{Methods}

\subsubsection{Vapor Permeability and Water Vapor Transmission Rate (WVTR)}

The ability of a porous material to transfer moisture due to a vapour pressure gradient can be expressed by the vapour permeability of the material. The transfer of moisture during this process can take place due to three factors: diffusion (self-collision of water molecules), effusion (collision of water molecules with the pore walls), and liquid transfer (associated with capillary condensation) [42].

The vapor permeability and the WVTR of the composite membranes were determined according to ASTM standard E 96 using the wet cup method. The data used in this analysis were obtained a dynamic vapour sorption equipment DVS Advantage, SMS, London, UK. A SMS Payne Type Diffusion cell was used in this test that is specially designed to measure the permeability and moisture transmission rate of thin films in the DVS instrument. The Payne cell has two main components: cell lid that holds the test sample and a cell cup with a small reservoir. The test samples were cut to a diameter of $15.5-16.0 \mathrm{~mm}$ to perfectly fit in the Payne cell lid. The Payne cell cup was filled with $200 \mu \mathrm{L}$ of water and the sample was placed between two O-rings. The bottom cell cup was screwed into the upper cell lid and placed on a metal sample pan for measurement in the DVS instrument. The samples were initially conditioned for $30 \mathrm{~min}$ at $95 \% \mathrm{RH}$ and $25^{\circ} \mathrm{C}$. The test was run under $50 \%$ $\mathrm{RH}$ and $25^{\circ} \mathrm{C}$ for $24 \mathrm{~h}$ and the cell was auto-weighed every minute by a DVS high mass ultra balance. The cell opening provided an active area of $113 \mathrm{~mm}^{2}$ for moisture transport. The sample thickness was measured using a micrometer and varied between the specimens $(100-500 \mu \mathrm{m})$. The tests were performed in triplicate and the average reading was reported.

The WVTR was determined by dividing the slope of the linear portion of the weight gain versus time curve by the tested surface area (interior cell area $=113 \mathrm{~mm}^{2}$ ) of the sample using the following equation:

$$
\operatorname{WVTR}\left(\frac{\mathrm{g}}{\mathrm{h} \cdot \mathrm{m}^{2}}\right)=\frac{\text { slope }(\mathrm{g} / \mathrm{h})}{\text { cell area }\left(\mathrm{m}^{2}\right)}
$$

WVTR describes the rate of water permeating through a test specimen into the headspace volume of a container, which differs in relative humidity $(\Delta \mathrm{RH})$.

Vapor permeability, $\mathrm{P}$ hence is represented as:

$$
\mathrm{P}\left(\frac{\mathrm{g}}{\mathrm{h} \cdot \mathrm{m} \cdot \mathrm{Pa}}\right)=\frac{\mathrm{WVTR}\left(\mathrm{g} / \mathrm{h} \cdot \mathrm{m}^{2}\right) \cdot \mathrm{d}(\mathrm{m})}{\Delta \mathrm{P}(\mathrm{Pa})\left(\mathrm{m}^{2}\right)}
$$

where $\mathrm{d}$ is the test specimen thickness (m)

It is simpler to compare WVTR between samples with varying thicknesses, by eliminating the thickness factor and reporting it as:

$$
\text { Normalized WVTR }\left(\frac{\mathrm{g}}{\mathrm{h} \cdot \mathrm{m}}\right)=\operatorname{WVTR}\left(\frac{\mathrm{g}}{\mathrm{h} \cdot \mathrm{m}^{2}}\right) \cdot \mathrm{d}(\mathrm{m})
$$

\subsubsection{Water Retention}

The water retention test was performed according to ASTM D-570-95 using the $24 \mathrm{~h}$ immersion test method. The specimen was placed in a container of water at room temperature, rested at its edge and entirely immersed. At the end of $24 \mathrm{~h}$, the specimen was removed from water, wiped free of surface moisture with a dry cloth, and weighed to the nearest $0.001 \mathrm{~g}$ immediately. The test was performed in triplicates and the average reading was reported. The test specimens were thin films of $150 \mathrm{~mm}$ in diameter.

The percentage of water absorption (WA) was calculated according to the following equation:

$$
\mathrm{WA}=\frac{\mathrm{m}_{24}-\mathrm{m}_{0}}{\mathrm{~m}_{0}} \times 100
$$


where $\mathrm{m}_{0}$ is the initial mass of the test specimen $(\mathrm{g}), \mathrm{m}_{24}$ is the mass of the test specimen after partial immersion for $24 \mathrm{~h}(\mathrm{~g})$.

\subsubsection{Scanning Electron Microscopy}

Photomicrographs of the samples were captured using a Thermo Fisher Scientific Scanning Electron Microscope (SEM), model FEI Quanta 250 (Hillsboro, OR, USA) operating at $15 \mathrm{kV}$. The samples were gold coated to obtain high magnification of morphology and texture.

\subsubsection{Thermogravimetric Analysis}

The thermal degradation behaviour of samples was studied using a thermogravimetric analyser TGA/DTA 851e Mettler Toledo instrument (Columbus, OH, USA). Approximately 8-10 mg of sample was placed in an uncovered $70 \mu \mathrm{L}$ alumina crucible to determine mass loss during heating. The specimens were heated at a rate of $10^{\circ} \mathrm{C} / \mathrm{min}$ from 25 to $950{ }^{\circ} \mathrm{C}$ under nitrogen atmosphere purged at $50 \mathrm{~mL} / \mathrm{min}$. The test was performed in triplicate.

\subsubsection{Differential Scanning Calorimetry}

The melting point and enthalpy of the samples were determined by a differential scanning calorimeter DSC Mettler Toledo 822/e (Columbus, OH, USA). Approximately $7 \mathrm{mg}$ of sample was placed in a sealed aluminium cell to determine melting and glass transition temperatures and enthalpies during heating. The samples were heated from $25^{\circ} \mathrm{C}$ to $250^{\circ} \mathrm{C}$ at $10^{\circ} \mathrm{C} / \mathrm{min}$ under nitrogen. The test was performed in triplicate.

\subsubsection{Dynamic Mechanical Analysis}

Glass transition temperature ( $\mathrm{Tg}$ ) was determined by dynamic mechanical analysis based on the maximum of the tan delta peak, which represents the ratio of storage modulus to loss modulus. The tests were conducted using a Q800 dynamic mechanical analyzer (DMA) from TA instruments, New Castle, DE, USA. The tests were conducted in tension mode at a frequency of $1 \mathrm{~Hz}$ and an amplitude of $10 \mu \mathrm{m}$. The test samples were cut from the films using a laser machine having a dimension of $20 \mathrm{~mm}$ (length) by $4.5 \mathrm{~mm}$ (wide) and approximate thickness of $0.2 \mathrm{~mm}$. All specimens were initially conditioned at $25^{\circ} \mathrm{C}$ in the DMA chamber, and then dynamic heating scans were performed from 25 to $150{ }^{\circ} \mathrm{C}$ at $3{ }^{\circ} \mathrm{C} / \mathrm{min}$. The test was performed in triplicate and the average reading was reported.

\section{Results and Discussion}

Moisture transfer in porous materials takes place due to the presence of a vapour pressure gradient between their top and bottom surfaces. Figure 3 represents the water vapour transmission rate (WVTR) of the prepared membranes. It was seen that, overall, the vapour transmission increased with increasing CF content in the samples. The detailed data analysis of vapour permeability of the composites is reported in Table 2.

The normalized WVTR is an important factor to consider when measuring permeability of composites with different thicknesses. The WVTR of the PLA-TCF was similar to PLA-UCF composites at lower CF concentrations. As the CF concentration increased beyond $10 \%$, the composites with treated fibers showed significantly lower vapor transmission rates. The WVTR of PLA-TCF20 was 73\% lower than that of PLA-UCF20. The increase in vapour permeability and WVTR at higher CF concentration is linked to the pore network and structure of the composite. The surfactant treatment resulted in good dispersion of fibers in the PLA matrix, thereby reducing formation of voids and limiting capillary movement of water molecules. The treatment, however, did not completely block microscopic pores in the samples that are needed for vapour diffusion. 


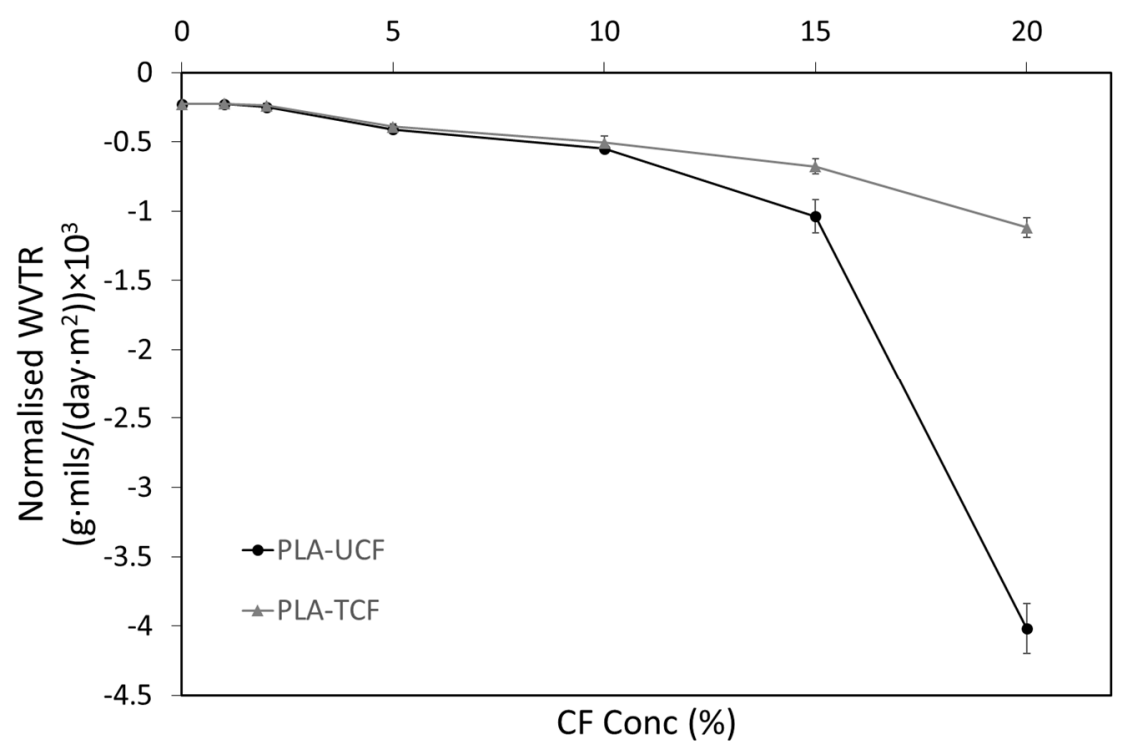

Figure 3. WVTR of the films with varying CF concentration.

Table 2. Vapor permeability results of the films.

\begin{tabular}{|c|c|c|c|c|c|}
\hline Sample & $\begin{array}{c}\text { WVTR } \\
\left(\mathrm{g} /\left(\mathrm{h} \cdot \mathrm{m}^{2}\right)\right)\end{array}$ & $\begin{array}{l}\text { Thickness } \\
\text { (mm) }\end{array}$ & $\begin{array}{c}\text { Permeability P } \\
(\mathrm{g} /(\mathrm{h} \cdot \mathrm{m} \cdot \mathrm{Pa})) \times 10^{-7}\end{array}$ & $\begin{array}{l}\text { Normalized WVTR } \\
\left(\mathrm{g} \cdot \mathrm{m} /\left(\mathrm{h} \cdot \mathrm{m}^{2}\right)\right) \times 10^{-5}\end{array}$ & $\begin{array}{c}\text { Normalized } \\
\text { WVTR } \\
\left(\mathrm{g} \cdot \mathrm{mils} /\left(\mathrm{day} \cdot \mathrm{m}^{2}\right)\right)\end{array}$ \\
\hline PLA & $-2.21 \pm 0.03$ & $0.11 \pm 0.01$ & $-2.01 \pm 0.12$ & $-24.33 \pm 1.47$ & $-229.90 \pm 13.96$ \\
\hline PLA-UCF1 & $-1.26 \pm 0.04$ & $0.19 \pm 0.01$ & $-1.99 \pm 0.03$ & $-24.09 \pm 0.34$ & $-227.65 \pm 3.26$ \\
\hline PLA-UCF2 & $-1.32 \pm 0.04$ & $0.20 \pm 0.01$ & $-2.19 \pm 0.02$ & $-26.54 \pm 0.25$ & $-250.83 \pm 2.38$ \\
\hline PLA-UCF5 & $-1.70 \pm 0.06$ & $0.26 \pm 0.02$ & $-3.66 \pm 0.13$ & $-44.31 \pm 1.59$ & $-418.68 \pm 15.05$ \\
\hline PLA-UCF10 & $-1.98 \pm 0.03$ & $0.30 \pm 0.01$ & $-4.92 \pm 0.14$ & $-59.60 \pm 1.74$ & $-563.19 \pm 16.49$ \\
\hline PLA-UCF15 & $-3.16 \pm 0.24$ & $0.32 \pm 0.02$ & $-8.36 \pm 0.54$ & $-101.15 \pm 6.71$ & $-955.79 \pm 60.04$ \\
\hline PLA-UCF20 & $-10.28 \pm 0.16$ & $0.42 \pm 0.02$ & $-35.71 \pm 1.58$ & $-432.14 \pm 19.12$ & $-4083.21 \pm 181.20$ \\
\hline PLA-TCF1 & $-1.28 \pm 0.03$ & $0.19 \pm 0.01$ & $-2.01 \pm 0.12$ & $-24.40 \pm 1.46$ & $-230.60 \pm 13.80$ \\
\hline PLA-TCF2 & $-1.42 \pm 0.04$ & $0.19 \pm 0.01$ & $-2.24 \pm 0.11$ & $-27.16 \pm 1.34$ & $-256.61 \pm 12.71$ \\
\hline PLA-TCF5 & $-1.79 \pm 0.06$ & $0.25 \pm 0.01$ & $-3.71 \pm 0.20$ & $-44.87 \pm 2.45$ & $-423.97 \pm 23.21$ \\
\hline PLA-TCF10 & $-2.97 \pm 0.13$ & $0.20 \pm 0.01$ & $-4.91 \pm 0.39$ & $-59.46 \pm 4.80$ & $-561.85 \pm 45.38$ \\
\hline PLA-TCF15 & $-2.61 \pm 0.10$ & $0.26 \pm 0.02$ & $-5.61 \pm 0.49$ & $-67.92 \pm 5.97$ & $-641.81 \pm 56.41$ \\
\hline PLA-TCF20 & $-4.79 \pm 0.15$ & $0.25 \pm 0.01$ & $-9.92 \pm 0.61$ & $-119.97 \pm 7.40$ & $-1133.58 \pm 69.90$ \\
\hline
\end{tabular}

The increase in the water vapour permeability at higher humidity level is related to the enhanced transport of moisture. This phenomenon is induced by the transfer of liquid in the microscopic pores of the material that are filled with water due to capillary condensation [42]. For materials that show hysteresis in their sorption isotherm, it has been reported earlier that their water vapour permeability is dependent on the moisture content [43].

The water absorption of the composites was calculated as percentage of absorption with respect to initial mass. As seen in Figure 4, the water absorption behaviour of the composites was significantly affected by the treatment of CF keeping the WA values to a minimum. PLA-UCF composites showed higher water absorption due to the absence of treatment on CF. PLA-UCF20 showed the highest absorption having a WA value of over $7 \%$ for $24 \mathrm{~h}$ immersion. 


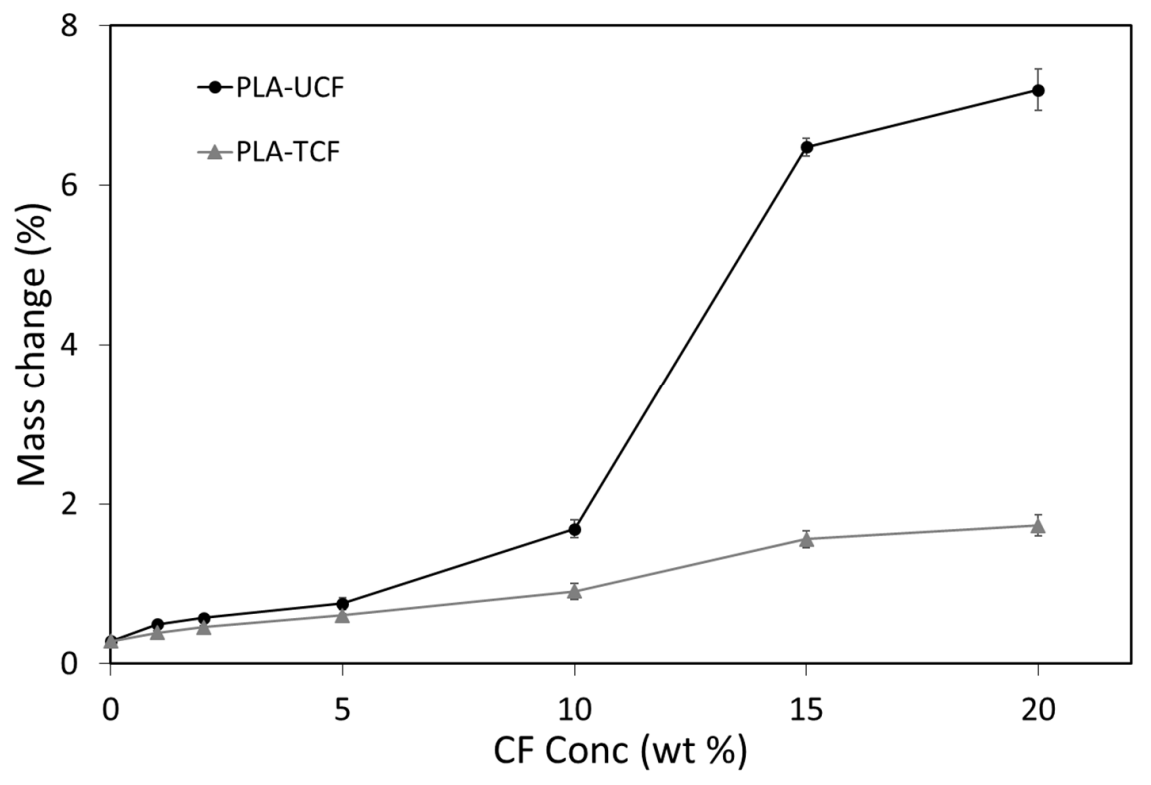

Figure 4. Water absorption behaviour of the films with varying CF concentration.

When compared to the treated fiber composite having the same CF concentration (PLA-TCF20), PLA-UCF20 showed a four-fold increase in water absorption. In addition to enhanced dispersion due to the $\mathrm{CF}$ treatment, it is evident that the chemical structure of the $\mathrm{CF}$ has also been altered, reducing available surface hydroxyl groups that are responsible for the higher water uptake in the samples.

A close examination of the composite morphology revealed that samples without CF treatment showed poor dispersion in the PLA matrix whereas the treatment was found to be effective for preparing homogenous PLA-CF samples. In Figure $5 b, c$, it can be seen that the untreated fibers and PLA have poor interfacial adhesion and the fibers show agglomeration at the surface. On the other hand, Figure 5d,e show that samples with surfactant treated CF are well dispersed in the PLA matrix.

The presence of the acid phosphate ester surfactant on the surface of nanocellulose facilitates their dispersion in the polymer matrix and improves the nucleation effect [40,44,45]. The surfactant acts as a stabilizing agent for obtaining a stable dispersion of cellulose fibers in the matrix $[46,47]$. The surfactant treatment has also been found to be effective in preventing the agglomeration of $\mathrm{CF}$ in solvents such as chloroform, thereby enhancing dispersibility in the polymer matrix [48].

The thermal properties of the PLA-CF films were investigated by TGA, DSC, and DMA analysis to determine the effect of surfactant treatment on the thermal stability of the polymer composites. The thermal characteristics of the composites are mentioned in Table 3.

Table 3. Thermal properties of films and fibers.

\begin{tabular}{cccccc}
\hline Sample & $\begin{array}{c}\text { Melting } \\
\text { Point }\left({ }^{\circ} \mathbf{C}\right)\end{array}$ & $\begin{array}{c}\text { Melting } \\
\text { Enthalpy }(\mathbf{m J})\end{array}$ & $\begin{array}{c}\text { Tg } \\
\left({ }^{\circ} \mathbf{C}\right)\end{array}$ & $\begin{array}{c}\text { Tmax } \\
\left({ }^{\circ} \mathbf{C}\right)\end{array}$ & $\begin{array}{c}\text { Residue } \\
(\mathbf{\%})\end{array}$ \\
\hline PLA & $153.6 \pm 0.9$ & $-128.6 \pm 0.3$ & $61.5 \pm 0.5$ & $368.1 \pm 0.2$ & $0.5 \pm 0.01$ \\
PLA-UCF20 & $153.5 \pm 0.6$ & $-90.6 \pm 0.2$ & $61.3 \pm 0.3$ & $354.9 \pm 0.1$ & $2.4 \pm 0.04$ \\
PLA-TCF20 & $153.7 \pm 0.5$ & $-120.2 \pm 0.3$ & $65.5 \pm 0.5$ & $372.5 \pm 0.1$ & $3.6 \pm 0.03$ \\
UCF & - & - & - & $361.2 \pm 0.3$ & $8.4 \pm 0.04$ \\
TCF & - & - & - & $269.3 \pm 0.2$ & $23.8 \pm 0.12$ \\
\hline
\end{tabular}




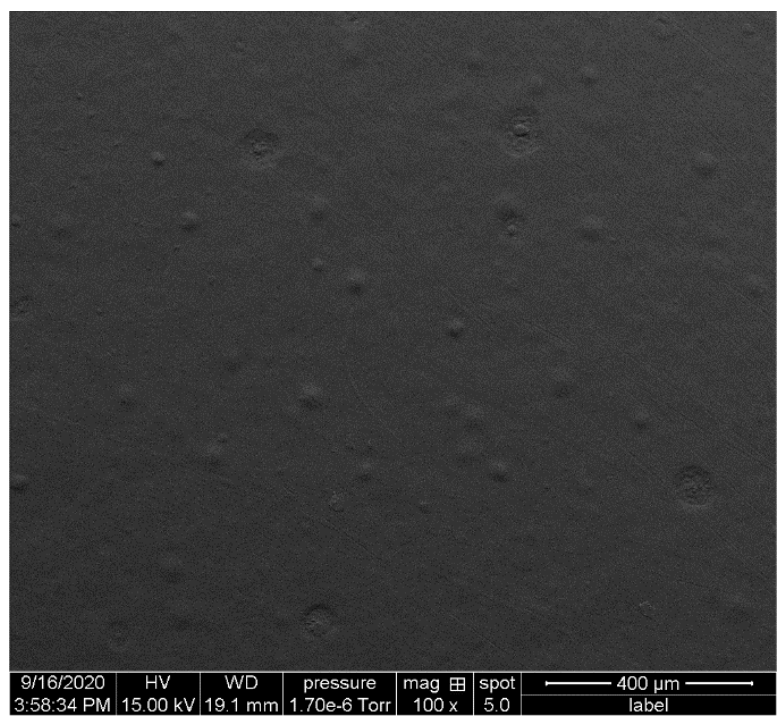

(a)

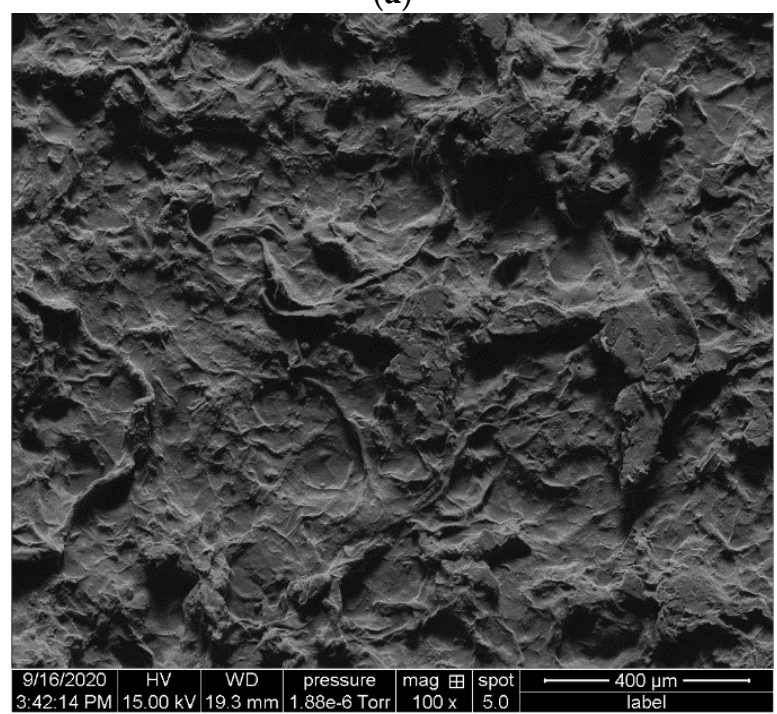

(b)

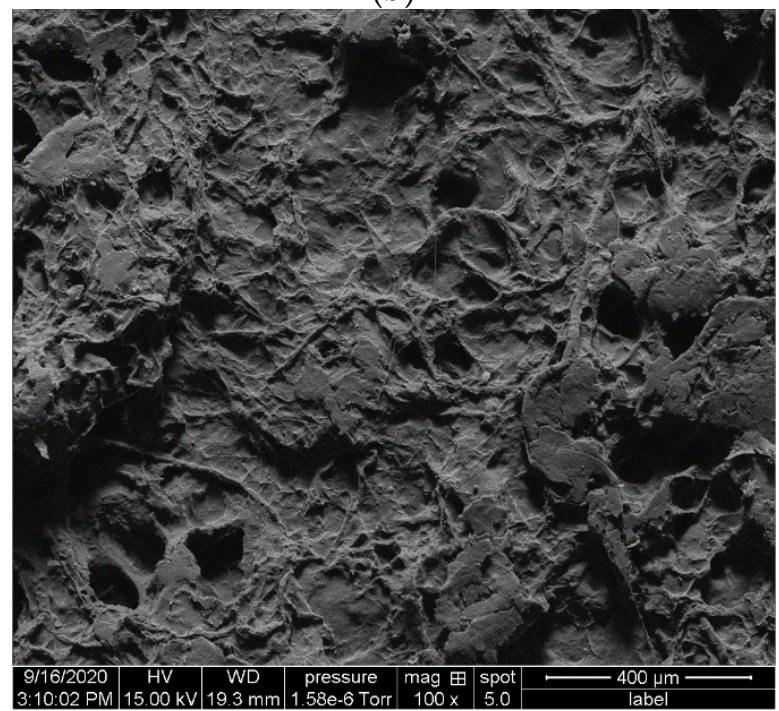

(c)

Figure 5. Cont. 


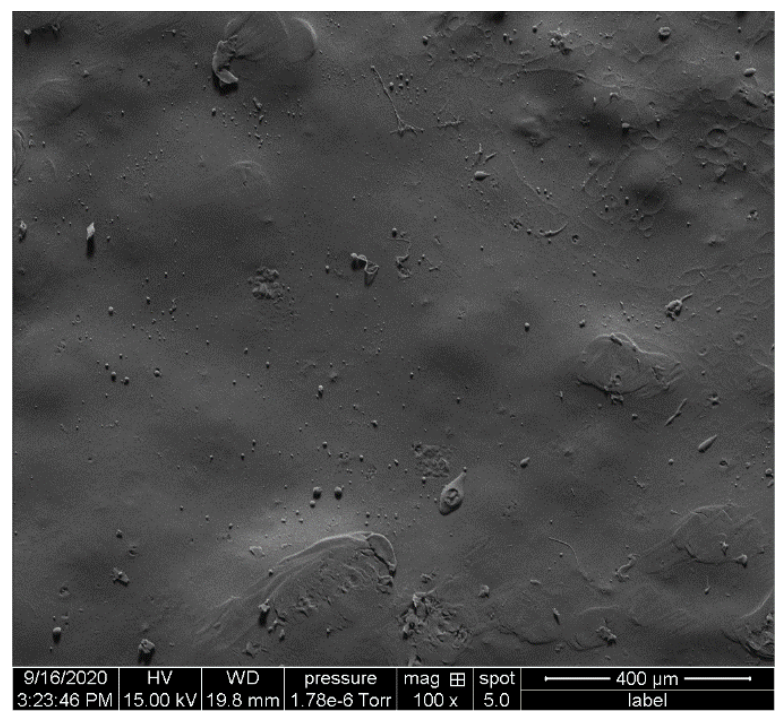

(d)

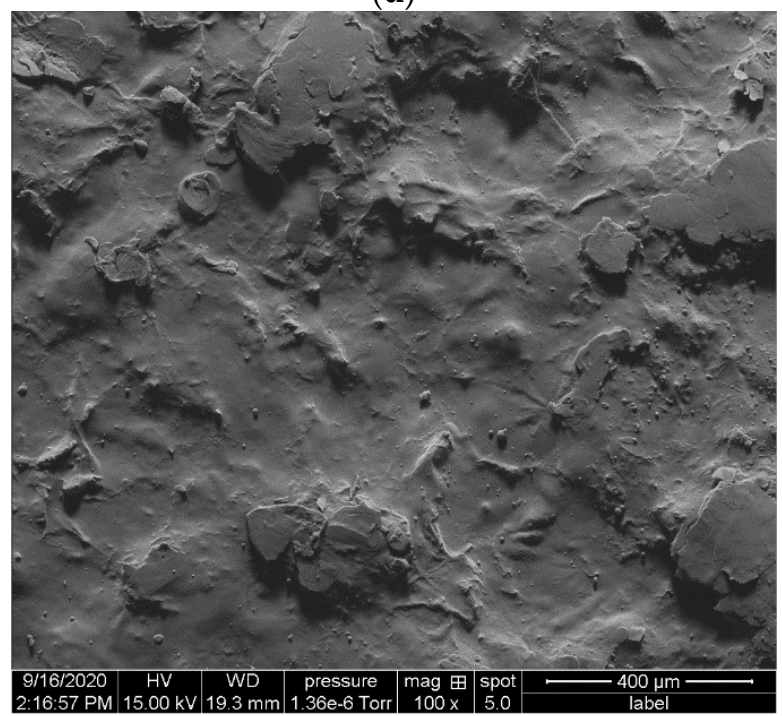

(e)

Figure 5. Micrograph of prepared films (a) PLA; (b) PLA-UCF10; (c) PLA-UCF20; (d) PLA-TCF10 and; (e) PLA-TCF20.

Thermogravimetric analysis of PLA, untreated and treated CF and the composite films shows a multistep degradation as seen in Figure 6. The initial step $\left(50-100^{\circ} \mathrm{C}\right)$ can be attributed to a loss of moisture. The treated CF shows lower thermal stability and weight loss between $250-300{ }^{\circ} \mathrm{C}$ corresponding to its respective DTG peaks in Figure 7 which are mainly associated with the effect of the surfactant on the fiber [46,48]. The PLATCF20 shows a smaller degradation peak corresponding to the surfactant coated fibers in the matrix. 


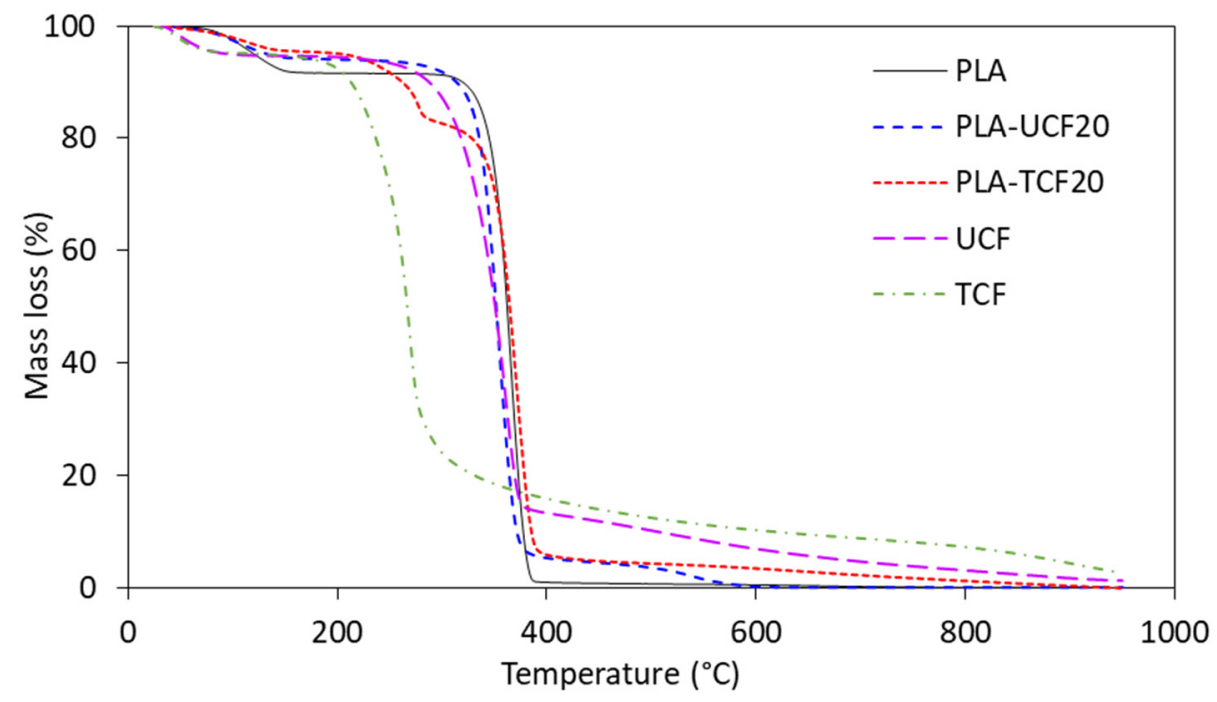

Figure 6. TGA curves of films and fibers with and without treatment.

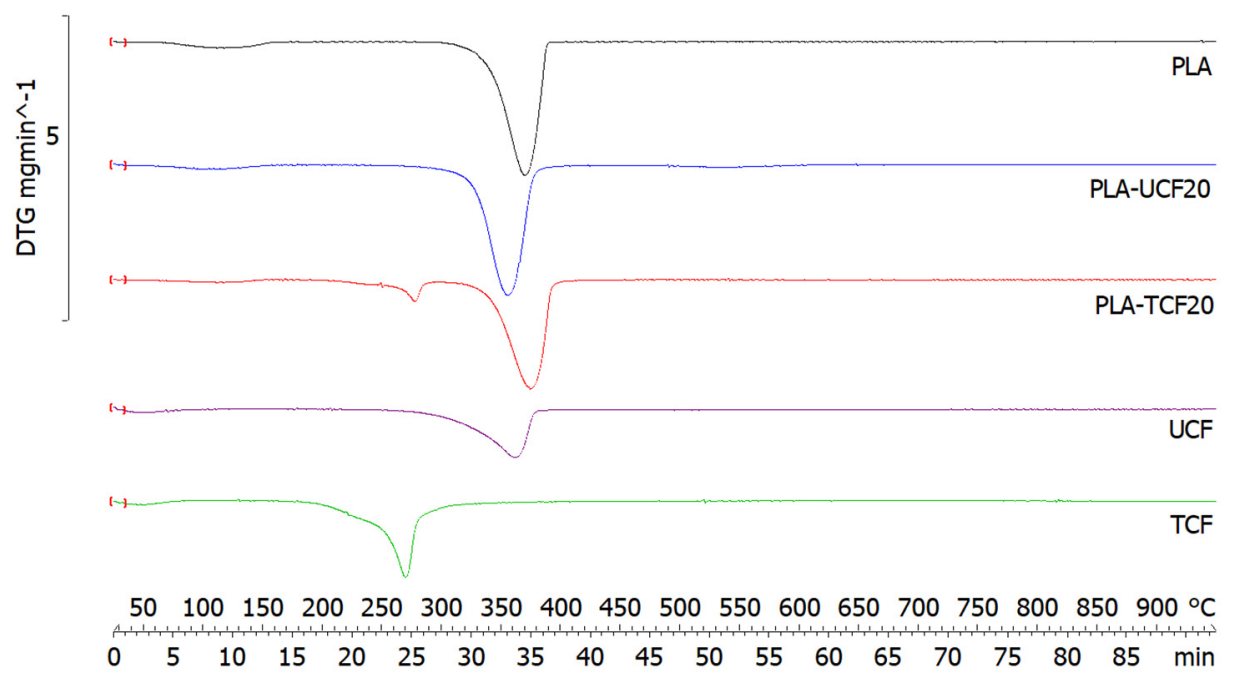

Figure 7. DTG curves of films and fibers with and without treatment.

The next main degradation step for all samples occurs between 350 and $400{ }^{\circ} \mathrm{C}$, associated with the cellulose, hemicellulose, and thermally stable compounds in the polymer matrix. The main DTG peak corresponding to the peak degradation temperature (Tmax) for PLA was $368{ }^{\circ} \mathrm{C}$ and for the PLA-CF samples it was between 354 and $372{ }^{\circ} \mathrm{C}$, showing that there was no degradation taking place in the composites at lower temperatures. It was observed that the addition of TCF in PLA slightly increases the thermal stability of the matrix due to better reinforcement as seen in Table 3.

Figure 8 shows the endothermic melting peaks for neat PLA, PLA-UCF20, and PLATCF20 composites. The three materials displayed similar curves and minor differences in their melting temperatures were observed, indicating that $\mathrm{CF}$ dispersion does not significantly affect the thermal properties of the polymer matrix. 


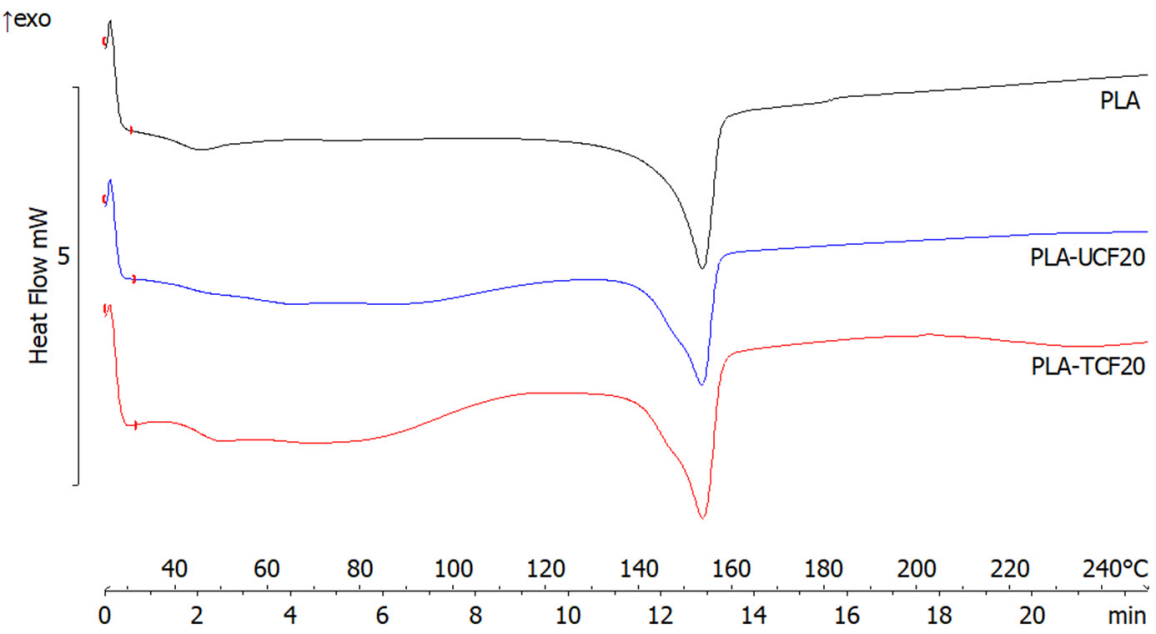

Figure 8. DSC curves of films with and without CF treatment.

From the DMA analysis, the glass transition temperatures $(\mathrm{Tg})$ of the composites were evaluated using the tan $\delta$ peak temperature. It was found that both the fiber content as well as fiber treatment had an effect on the $\mathrm{Tg}$, as seen in Figure 9.

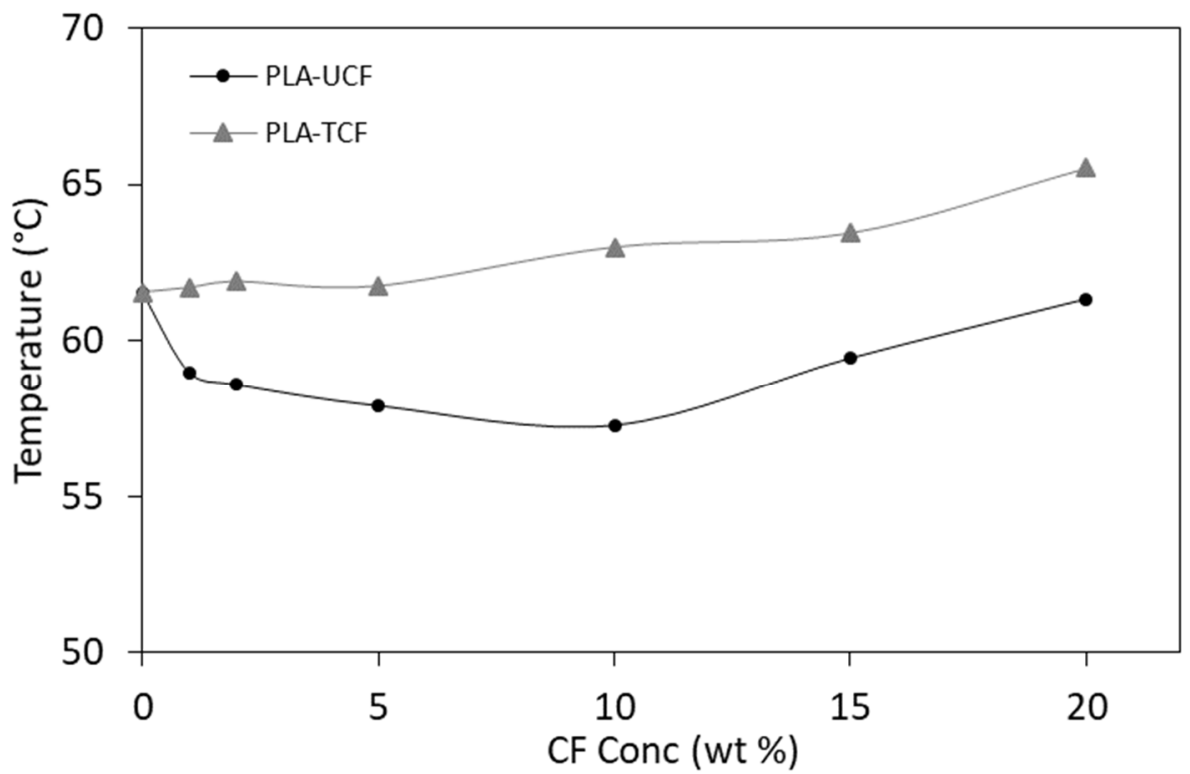

Figure 9. Glass transition temperature of films with varying CF concentration.

PLA composites prepared with surfactant treated fibers showed relatively higher $\mathrm{Tg}$ when compared to PLA composites containing untreated CF. The improvement in $\mathrm{Tg}$ (up to $10 \%$ ) could be associated with the enhanced CF dispersion and interface compatibility due to surface modification. On the other hand, the PLA-UCF composites showed a lower $\mathrm{Tg}$ compared to neat PLA. This could be due to the presence of residual water in the system, which causes a degradation of PLA. Moreover, it was observed that the Tg increased with higher CF content in the PLA composites. The addition of acid phosphate ester-based surfactant has been reported to enhance dispersibility, mechanical, and stress-transfer properties of cellulose reinforced composites [49].

\section{Conclusions}

The preparation of bio-based PLA membranes incorporating micro-fibrillated cellulose fiber $(\mathrm{CF})$ using a solvent casting method have been reported in this paper. The effects of $\mathrm{CF}$ 
modification, using an anionic organic phosphoric acid ester-based surfactant, on composite structure, morphology, and properties were investigated. The physical properties of the composite were significantly enhanced when prepared with treated CF. The composites containing treated CF absorbed very low amounts of water, even at $20 \mathrm{wt} \% \mathrm{CF}$ loading, yet these composites were permeable to water vapour. The $\mathrm{CF}$ treatment resulted in a good dispersion of fibers in the PLA matrix, as seen using scanning electron microscopy, thereby reducing void formation and limiting capillary movement. However, the incorporation of treated CF did not completely block the microscopic pores in the composite samples that are needed for vapour diffusion, as seen in the vapour permeability results. The CF treatment also improved the thermal properties of the composite, increasing their glass transition temperature and peak degradation temperature. The melting point of the composites did not change before and after $\mathrm{CF}$ treatment. The prepared composites were breathable and showed better resistance to water. Using a relatively inexpensive treatment, smart biobased membranes have been developed that have great potential in the building industry by increasing the hygroscopic performance as well as reducing the embodied energy of buildings. Further work is recommended considering the durability and weathering of the PLA-CF composites as well as the preparation of larger sized films and assessment of their hygroscopic performance in test cells.

Author Contributions: Conceptualization, A.H. and P.B.; methodology, A.H. and P.B.; formal analysis, A.H.; investigation, A.H.; resources, P.B.; data curation, A.H.; writing—original draft preparation, A.H.; writing-review and editing, A.H. and P.B.; visualization, A.H.; supervision, P.B.; project administration, P.B.; funding acquisition, A.H. and P.B. All authors have read and agreed to the published version of the manuscript.

Funding: The authors are grateful to Natural Sciences and Engineering Research Council of Canada for the financial support through its IRC and CRD programs (IRCPJ 461745-18 and RDCPJ 524504-18) as well as the industrial partner, Kruger Inc., of the NSERC industrial chair on eco-responsible wood construction (CIRCERB). This work was also supported by the funds received from Quebec Research Funds - Nature and Technology (FRQNT) under the Merit Scholarship Program for Foreign Students, Quebec-India Postdoctoral scholarships (PBEEE 2I, 2019-2020).

Informed Consent Statement: Not applicable.

Data Availability Statement: The data presented in this study are available on request from the corresponding author.

Conflicts of Interest: The authors declare no conflict of interest. The funders had no role in the design of the study; in the collection, analyses, or interpretation of data; in the writing of the manuscript, or in the decision to publish the results.

\section{References}

1. Viel, M.; Collet, F.; Lecieux, Y.; François, M.L.M.; Colson, V.; Lanos, C.; Hussain, A.; Lawrence, M. Resistance to mold development assessment of bio-based building materials. Compos. Part B Eng. 2019, 158, 406-418. [CrossRef]

2. Wilkinson, J.; Ueno, K.; De Rose, D.; Straube, J.F.; Fugler, D. Understanding Vapour Permeance and Condensation in Wall Assemblies. In Proceedings of the 11th Canadian Building Science \& Technology Conference, National Building Envelope Council 2007, Banff, AB, Canada, 3-5 November 2007; pp. 1-14.

3. Agarwal, S.; Gupta, R.K. Plastics in Buildings and Construction. In Applied Plastics Engineering Handbook: Processing, Materials, and Applications, 2nd ed.; Elsevier: Amsterdam, The Netherlands, 2017; pp. 635-649. ISBN 9780323390408.

4. Lstiburek, J.W. Understanding vapor barriers. ASHRAE J. 2004, 46, 40-47.

5. Hussain, A.; Calabria-Holley, J.; Lawrence, M.; Jiang, Y. Hygrothermal and mechanical characterisation of novel hemp shiv based thermal insulation composites. Constr. Build. Mater. 2019, 212, 561-568. [CrossRef]

6. Latif, E.; Tucker, S.; Ciupala, M.A.; Wijeyesekera, D.C.; Newport, D. Hygric properties of hemp bio-insulations with differing compositions. Constr. Build. Mater. 2014, 66, 702-711. [CrossRef]

7. Stroeks, A. The moisture vapour transmission rate of block co-poly(ether- ester) based breathable films. 2. Influence of the thickness of the air layer adjacent to the film. Polymer 2001, 42, 09903-09908. [CrossRef]

8. Straube, J.; Schumacher, C. Interior insulation retrofits of load-bearing masonry walls in cold climates. J. Green Build. 2007, 2, 42-50. [CrossRef] 
9. Straube, J.F. The influence of low-permeance vapor barriers on roof and wall performance. In Proceedings of the Thermal Performance of Whole Buildings VIII, Clearwater, FL, USA, 2-7 December 2001; pp. 1-12.

10. Lafond, C.; Blanchet, P. Technical performance overview of bio-based expanded polystyrene. Buildings 2020, 10, 81. [CrossRef]

11. Jiang, Y.; Lawrence, M.; Hussain, A.; Ansell, M.; Walker, P. Comparative moisture and heat sorption properties of fibre and shiv derived from hemp and flax. Cellulose 2019, 26, 823-843. [CrossRef]

12. Ansell, M.P.; Lawrence, M.; Jiang, Y.; Shea, A.; Hussain, A.; Calabria-Holley, J.; Walker, P. Natural Plant-Based Aggregates and Bio-Composite Panels with Low Thermal Conductivity and High Hygrothermal Efficiency for Applications in Construction; Elsevier: Amsterdam, The Netherlands, 2019; ISBN 9780081027042.

13. Segovia, F.; Blanchet, P.; Auclair, N.; Essoua Essoua, G.G. Thermo-Mechanical Properties of a Wood Fiber Insulation Board Using a Bio-Based Adhesive as a Binder. Buildings 2020, 10, 152. [CrossRef]

14. Cabral, M.R.; Blanchet, P. A state of the art of the overall energy efficiency of wood buildings-An overview and future possibilities. Materials 2021, 14, 1848. [CrossRef]

15. Maskell, D.; Thomson, A.; Walker, P.; Lemke, M. Determination of optimal plaster thickness for moisture buffering of indoor air. Build. Environ. 2018, 130, 143-150. [CrossRef]

16. Tran Le, A.D.; Maalouf, C.; Mai, T.H.; Wurtz, E.; Collet, F. Transient hygrothermal behaviour of a hemp concrete building envelope. Energy Build. 2010, 42, 1797-1806. [CrossRef]

17. Lawrence, M. Reducing the Environmental Impact of Construction by Using Renewable Materials. J. Renew. Mater. 2015, 3, 163-174. [CrossRef]

18. MELCC. Politique-Cadre D'Électrification et de Lutte Contre Les Changements Climatiques; Gouvernement du Québec: Québec, QC, Canada, 2020; ISBN 9782550862796.

19. Lessard, Y.; Anand, C.; Blanchet, P.; Frenette, C.; Amor, B. LEED v4: Where Are We Now? Critical Assessment through the LCA of an Office Building Using a Low Impact Energy Consumption Mix. J. Ind. Ecol. 2018, 22, 1105-1116. [CrossRef]

20. Phanthong, P.; Reubroycharoen, P.; Hao, X.; Xu, G.; Abudula, A.; Guan, G. Nanocellulose: Extraction and application. Carbon Resour. Convers. 2018, 1, 32-43. [CrossRef]

21. Abdul Khalil, H.P.S.; Bhat, A.H.; Ireana Yusra, A.F. Green composites from sustainable cellulose nanofibrils: A review. Carbohydr Polym. 2012, 87, 963-979. [CrossRef]

22. Jonoobi, M.; Harun, J.; Mathew, A.P.; Oksman, K. Mechanical properties of cellulose nanofiber (CNF) reinforced polylactic acid (PLA) prepared by twin screw extrusion. Compos. Sci. Technol. 2010, 70, 1742-1747. [CrossRef]

23. Sharma, A.; Thakur, M.; Bhattacharya, M.; Mandal, T.; Goswami, S. Commercial application of cellulose nano-compositesA review. Biotechnol. Rep. 2019, 21, e00316. [CrossRef]

24. Erbas Kiziltas, E.; Kiziltas, A.; Bollin, S.C.; Gardner, D.J. Preparation and characterization of transparent PMMA-cellulose-based nanocomposites. Carbohydr. Polym. 2015, 127, 381-389. [CrossRef]

25. Spence, K.L.; Venditti, R.A.; Rojas, O.J.; Pawlak, J.J.; Hubbe, M.A. Water Vapor Barrier Properties of Microfibrillated Cellulose Films. BioResources 2011, 6, 4370-4388. [CrossRef]

26. Song, Z.; Xiao, H.; Zhao, Y. Hydrophobic-modified nano-cellulose fiber/PLA biodegradable composites for lowering water vapor transmission rate (WVTR) of paper. Carbohydr. Polym. 2014, 111, 442-448. [CrossRef] [PubMed]

27. Fortunati, E.; Peltzer, M.; Armentano, I.; Torre, L.; Jiménez, A.; Kenny, J.M. Effects of modified cellulose nanocrystals on the barrier and migration properties of PLA nano-biocomposites. Carbohydr. Polym. 2012, 90, 948-956. [CrossRef]

28. Hospodarova, V.; Stevulova, N. Investigation of Waste Paper Cellulosic Fibers Utilization into Cement Based Building Materials. Buildings 2018, 8, 43. [CrossRef]

29. Yi, T.; Zhao, H.; Mo, Q.; Pan, D.; Liu, Y.; Huang, L.; Xu, H. From Cellulose to Cellulose Nanofibrils-A Comprehensive Review of the Preparation and Modification of Cellulose Nanofibrils. Materials 2020, 13, 5062. [CrossRef] [PubMed]

30. Lawrence, M.; Fodde, E.; Paine, K.; Walker, P. Hygrothermal Performance of an Experimental Hemp-Lime Building. Key Eng. Mater. 2012, 517, 413-421. [CrossRef]

31. Stevulova, N.; Cigasova, J.; Schwarzova, I.; Sicakova, A.; Junak, J. Sustainable bio-aggregate-based composites containing hemp hurds and alternative binder. Buildings 2018, 8, 25. [CrossRef]

32. Cichosz, S.; Masek, A.; Rylski, A. Cellulose Modification for Improved Compatibility with the Polymer Matrix: Mechanical Characterization of the Composite Material. Materials 2020, 13, 5519. [CrossRef]

33. Kabir, M.M.; Wang, H.; Lau, K.T.; Cardona, F. Chemical treatments on plant-based natural fibre reinforced polymer composites: An overview. Compos. Part B Eng. 2012, 43, 2883-2892. [CrossRef]

34. Bledzki, A.K.; Mamun, A.A.; Lucka-Gabor, M.; Gutowski, V.S. The effects of acetylation on properties of flax fibre and its polypropylene composites. Express Polym. Lett. 2008, 2, 413-422. [CrossRef]

35. Phan-Xuan, T.; Thuresson, A.; Skepö, M.; Labrador, A.; Bordes, R.; Matic, A. Aggregation behavior of aqueous cellulose nanocrystals: The effect of inorganic salts. Cellulose 2016, 23, 3653-3663. [CrossRef]

36. Yasin, S.; Hussain, M.; Zheng, Q.; Song, Y. Large amplitude oscillatory rheology of silica and cellulose nanocrystals filled natural rubber compounds. J. Colloid Interface Sci. 2021, 588, 602-610. [CrossRef]

37. Yasin, S.; Hussain, M.; Zheng, Q.; Song, Y. Effects of ionic liquid on cellulosic nanofiller filled natural rubber bionanocomposites. J. Colloid Interface Sci. 2021, 591, 409-417. [CrossRef] [PubMed] 
38. Cerny, P.; Bartos, P.; Kriz, P.; Olsan, P.; Spatenka, P. Highly Hydrophobic Organosilane-Functionalized Cellulose: A Promising Filler for Thermoplastic Composites. Materials 2021, 14, 2005. [CrossRef] [PubMed]

39. Hussain, A.; Calabria-Holley, J.; Lawrence, M.; Ansell, M.P.; Jiang, Y.; Schorr, D.; Blanchet, P. Development of novel building composites based on hemp and multi-functional silica matrix. Compos. Part B Eng. 2019, 156, 266-273. [CrossRef]

40. Fortunati, E.; Rinaldi, S.; Peltzer, M.; Bloise, N.; Visai, L.; Armentano, I.; Jiménez, A.; Latterini, L.; Kenny, J.M. Nano-biocomposite films with modified cellulose nanocrystals and synthesized silver nanoparticles. Carbohydr. Polym. 2014, 101, 1122-1133. [CrossRef] [PubMed]

41. Kaboorani, A.; Riedl, B. Surface modification of cellulose nanocrystals (CNC) by a cationic surfactant. Ind. Crops Prod. 2015, 65, 45-55. [CrossRef]

42. Collet, F.; Chamoin, J.; Pretot, S.; Lanos, C. Comparison of the hygric behaviour of three hemp concretes. Energy Build. 2013, 62, 294-303. [CrossRef]

43. Derome, D.; Derluyn, H.; Zillig, W.A.; Carmeliet, J. Model for hysteretic moisture behaviour of wood. In Proceedings of the Nordic Symposium on Building Physics 2008, Copenhagen, Denmark, 16-18 June 2008; Volume 2, pp. 959-966.

44. Shamsuri, A.A.; Md Jamil, S.N.A. A short review on the effect of surfactants on the mechanico-thermal properties of polymer nanocomposites. Appl. Sci. 2020, 10, 4867. [CrossRef]

45. Fortunati, E.; Armentano, I.; Zhou, Q.; Iannoni, A.; Saino, E.; Visai, L.; Berglund, L.A.; Kenny, J.M. Multifunctional bionanocomposite films of poly(lactic acid), cellulose nanocrystals and silver nanoparticles. Carbohydr. Polym. 2012, 87, 1596-1605. [CrossRef]

46. Bondeson, D.; Oksman, K. Dispersion and characteristics of surfactant modified cellulose whiskers nanocomposites. Compos. Interfaces 2007, 14, 617-630. [CrossRef]

47. Heux, L.; Chauve, G.; Bonini, C. Nonflocculating and chiral-nematic self-ordering of cellulose microcrystals suspensions in nonpolar solvents. Langmuir 2000, 16, 8210-8212. [CrossRef]

48. Moreno, M.; Armentano, I.; Fortunati, E.; Mattioli, S.; Torre, L.; Lligadas, G.; Ronda, J.C.; Galià, M.; Cádiz, V. Cellulose nano-biocomposites from high oleic sunflower oil-derived thermosets. Eur. Polym. J. 2016, 79, 109-120. [CrossRef]

49. Ljungberg, N.; Cavaillé, J.Y.; Heux, L. Nanocomposites of isotactic polypropylene reinforced with rod-like cellulose whiskers. Polymer 2006, 47, 6285-6292. [CrossRef] 